Кто-то из его героев, например,Серпеев из рассказа «Наш человек в футляре», становится жертвой клеветы, а кто-то сам занимается наговором, как учителя из того же произведения. В бывшем СССР доносительство приобрело такой размах, что было возведено в ранг человеческой добродетели. Иронично создаются картины рьяного выявления глуповцами «тайных саботажников, явных недоброжелателей». Пострадали сто пятьдесят человек, «враждебно настроенных», и читатель понимает, что это только начало репрессий $[6,93]$.

Даже когда русский человек знает, что ему не поздоровится, он идет напролом, с завидным упорством пытаясь осуществить задуманное. В этом отношении показательна история братьев Милославских, которые решили нести просвещение в невежественные массы мужиков, за что до крови были избиты. Но и после этого братья не оставляют начатое дело, т.к. «ребята они были настырные, и если за что брались, то до крови из-под ногтей» $[6,93]$.

Таким образом,В.А. Пьецух в цикле «Плагиат» акцентирует внимание читателей на склонности русских к крайностям, которая довольно часто приводит к трагическому концу.

$$
* * *
$$

1. Пьецух В. Москва, санкт-петербургский вариант // Литературная газета. -17 мая1989.-№ 20. -С. 7

2. Бердяев Н. О власти пространства над русской душой. // Судьба России. - М., 1918.

3. Лихачев Д. С. О национальном характере русских. Вопросы философии. - 1990. - № 4. - С. 3-6.

4. Лосский Н.О. Характер русского народа. -Frankfurt am MainDeutschland: Посев.- 1957.

5. Достоевский Ф.М.Полное собрание сочинений: в 30 т. -Л.: Наука, 1973. -Т. 6.

6. ПьецухВ.А.Плагиат. - М.: Глобулус, НЦ ЭНАС, 2006. - 304 с.

\title{
Лалова Т.И. \\ О преподавании французского языка «с нуля» студентам технических специальностей
}

Российский университет транспорта (МИИТ)

(Россия, Москва)

doi: $10.18411 / s p c-26-12-2017-03$

idsp: 000001:spc-26-12-2017-03

\section{Аннотация}

Статья посвящена проблемам лингвистической подготовки студентов неязыковых ВУЗов. Речь идет о преподавании нового иностранного языка «с нуля» (в данном случае французского), отличного от изучаемого в школе (чаще всего английского). В статье анализируются законодательная сторона вопроса об участии студента в формировании содержания своего образования, методика и особенности обучения другому иностранному языку в Российском университете транспорта (МИИТ) с учётом требований Федерального государственного образовательного стандарта высшего образования 3++ и профессиональных стандартов. Рассматриваются цели и задачи обучения иностранному языку, отраженные в Рабочей программе по дисциплине «Иностранный язык». Делается вывод о роли иностранных языков в становлении молодых людей хорошими профессионалами, а также всесторонне развитыми, высокообразованными личностями.

Ключевые слова: иностранный язык, методика преподавания, образовательные стандарты, обучение иностранному языку «с нуля» студентов технических специальностей, высокообразованная личность. 


\section{Abstract}

The article is devoted to linguistic preparation of the students of non-linguistic universities. It describes the educational process of teaching students of the beginner level a new language (in this case French), which differs from the language they study at school (most often English). The article analyses the legal side of the students participation in making up the content of their education, methods and peculiarities of acquiring a foreign language at Russian University of Transport (MIIT) according to the requirements of the Federal state educational standard of higher education $3++$ and professional standards.

We discuss the goals and objectives of teachng a foreign language, included in the educational programme on discipline "Foreign language". The article presents the conclusion about the role of foreign languages that contribute to further professional development of young people and their becoming of broad-minded and highly-educated personalities.

Key words: a foreign language, methods of teaching, educational standards, teaching a foreign language for the beginner students of technical specialities, a highly-educated personality.

Происходящие в наши дни изменения в содержании подготовки будущих инженеров направлены на формирование не только высококлассного специалиста, но и широко образованного человека, на развитие его творческой инициативы, его конкурентоспособности и его мобильности. В современных условиях молодойспециалист - выпускник неязыкового ВУЗа все больше и большедолжен быть готов к установлению межкультурных научных и профессиональных связей, развитию деловых контактов, изучению зарубежного опыта в определённой области, участию в международных конференциях. Для этого ему просто необходимо владетьиностранными языками. Среди требований к выпускнику со стороны работодателей зачастую знание иностранных языков стоит на втором месте после профессиональной подготовки, опережая компьютерную грамотность. Поэтомупроблема изучения иностранных языков в неязыковых вузахсегодня особенно актуальна и важна.

При этом необходимо отметить, что изучение иностранных языков чаще всего предполагаетизучение английского,так как в настоящее время английский язык является самым распространенным средством межкультурной коммуникации, а также занимает лидирующие позиции среди иностранных языков, преподаваемых в средней школе. По этой же причине владение английским языком сегодня не является чем-то редким или исключительным. Поэтому, а также из-за усиливающейся конкуренции на рынке труда, знание одного английского языка может оказаться недостаточным для получения будущим инженером искомой должности. Другие международные языки также широко распространены и используются в качестве средства коммуникации в мире, а также во многих иностранных и совместных с Россией кампаниях, представленных на территории нашей страны. В связи с этим их изучение и знание могут стать решающими для выпускника в его будущей профессиональной деятельности.

Тут возникает вопрос, правомочен ли студент изучать в ВУЗе новый, отличный от «школьного» иностранный язык? В Федеральном законе от 29.12.2012 N 273-Ф3 «Об образовании в Российской Федерации», Федеральных государственных образовательных стандартах высшего профессионального образования третьего поколения указывается, что «каждый студент имеет право на участие в формировании содержания своего образования при условии обязательного соблюдения требований государственных образовательных стандартов высшего профессионального образования»[Федеральный закон..., с. 34, п. 4].Иначе говоря, преподавание студенту в ВУЗе выбранного иностранного языка, отличного от изучаемого им в школе, не является нарушением законодательства нашей страны. Иная информация по данному 
вопросу в вышеуказанных документах не содержится, другими нормативно-правовыми актами Российской Федерации также не регламентируется.

В отношении лингвистической подготовки это означает, чтообучающийся сам может решать, продолжать ли емуизучать язык (чаще всего английский), которым он занимался в школе, или начать учитьлюбойдругой из набора иностранных языков, предлагаемыхВУЗом в рамках образовательной программы.Для последнего ему необходимо написать заявление в учебный отдел института/факультета, указав, какой иностранный язык он хотел бы изучать.

Причины выбора другого - неанглийского иностранного языка могут быть совершенно разными. Существует немало случаев, когда студенты, поступившие в технический ВУЗ, больше увлекались в школе физикой и математикой. Их уровень подготовки по английскому языку как «непрофильному предмету» низкий. Трудности при освоении программы в школе были высокими. Отношение к предмету в этой связи отрицательное. Страх стать неуспевающим из-за нелюбимого предмета большой.

Случается, что учить английский надоедает, поскольку многие изучают его 9-11 лет в школе и сталкиваются с ним постоянно, тогда как другой иностранный язык воспринимается как что-то абсолютно новое, а значит и более интересное.

Есть еще одна категория студентов, которые предпочитают учить другой язык «с нуля». Это те, кто поступил в ВУЗ, имея высокий уровень знаний по английскому.Для таких студентов освоение неизвестного профессионального пласта лексикине представляет никакой сложности и не требует двух лет обучения. Именно их успешный результат при изучении английского языка выступает хорошей мотивацией для изучения другого.

Практика показывает, чтопочти всегда интерес и мотивация к обучению у студентов, выбравших другой язык, очень высокие. Это можно объяснить следующим:

- Другой иностранный язык изучается с самых азов, что создает студентам равные возможности в освоении предмета. С них не требуется хорошее знание школьной программы для продолженияобучения.

- Изучающий другой иностранный язык уже имеет опыт изучения одного иностранного языка. Этот процессдля него не новый, он его не пугает.

- Изучение второго иностранного языка идет с опорой как на русский, так и на английский языки. Многое студент усваивает по аналогии с ними.

Проблемы преподавания в техническом ВУЗе иностранных языков «с нуля» в методической литературеосвещаются не очень детально. Обычно указывается, что обучение другому языку происходит по тем же принципам, что и английскому, только в меньшем объёме. Однако на самом деле преподавание нового иностранного языка имеет целый ряд особенностей. Многолетний опыт работы со студентами - будущими инженерами Российского университета транспорта, изучающими французский язык на базе «школьного» английского - позволяет это утверждать.

Прежде всего, речь идет о более высоком темпе (особенно на начальном этапе) освоения учебного материала. В результате студенты, начавшие изучать новый иностранный язык, к концу второго курса осваивают ту же тематику (естественно, в меньшем объеме), что и студенты, которые продолжают заниматься английским. Причин для этого несколько.

1. Не надо изучать новый алфавит. Латинский алфавит студентам уже известен со школы.

2. Звуковой строй осваивается с использованием принципа имитации. Нет необходимости подробно излагать строение речевого аппарата, законы образования различных звуков, участие активных и пассивных органов речи в их образовании. Все эти понятия известны студентам из уроков английского.

3. Система согласных французского языканедалека от русской. Несколько объясненных особенностей произнесения французских согласных в большинстве 
случаев позволяют студентам не допускать грубых коммуникативных ошибок, мешающих пониманию смысла произносимого отрезка речи. Это же можно сказать в отношении фрикативного звука «Р», представляющего обычно наибольшую трудность. Если не получается его грассировать, можно произносить этот звук так же, как в русском. Ошибки в данном случае не будет, так как переднеязычное «Р» является одним из вариантов соответствующей фонемы. Так же не будет ошибки, но создаст «акцент» придыхание [t], как в английском. Надо отдельно тренировать французское (более близкое с русским) произношение [t].

4. Система французских гласных, особенно с учетом ее современных тенденций, также не представляет больших сложностейдля русскоговорящей аудитории. Принимая во внимание тот факт, что оппозиции между полуоткрытыми и полузакрытыми гласными (особенно в разговорном стиле) нейтрализуются, что используется одно «А» и три носовых фонемы вместо четырех, обучение гласным проходит достаточно легко. Необходимо обращать особое внимание на округленные [у] и [ое], а также на правильное произношение носовых гласных. Как и при введении системы согласных, необходимо объяснить особенности произношения гласных во французском языке.

5. Обучение чтению во французском языке идет по существующим строгим правилам. Транскрипцией для этого пользоваться не нужно. В связи с этим, уже на первом занятии обучающиеся самостоятельно по правилам могут прочитать несколько слов, и даже небольшие предложения.

6. Во французском, русском и английском языках имеется большое количество схожих лексических единиц и морфем. В этой связи обучении лексике и понимание нового изучаемого языка становятся более простыми. (Однако следует обращать особое внимание на «ложных друзей», то есть на слова со схожей или даже одинаковой орфографией, но различным значением. Такие пары встречаются при сравнении французского языка как с русским, так и с английским).

7. То же можно сказать и о грамматике. Похожие грамматические конструкции во французском, русском и английском позволяют изучать ее без подробного объяснения правил. Больше того, пока изучаемый материал прост, сложные правила можно вообще не объяснять. Полезнее тренировать наиболее употребляемые лексические и фразеологические единицы, синтаксические конструкции и глагольные формы.

Таким образом, преподавание нового иностранного языка проходит с широким использованием коммуникативной методики, которая как раз предполагает сведение к минимуму изучение сложного теоретического материала и позволяет уделять больше внимания функциональному языку, применяемому в реальных ситуациях коммуникации.Это отвечает положениям, заложенным во ФГОСедисциплины «иностранный язык» в неязыковом вузе о том, что преподавание должно носить коммуникативно-ориентированный, практический характер, «поскольку знания языка имеют для специалистов неязыкового профиля прикладную ценность»[Синицына, с. $151]$.

Одновременно с этим, согласно тому же стандарту преподавание иностранного языка должно быть профессионально-направленным. То есть специализация студентов, их будущая профессия предопределяют содержание обучения. Через иностранный язык, преподаваемый на 1-м и 2-м курсах университета, студенты часто получают первые профессиональные знания и навыки. В этой связи следует с сожалением отметить, что в настоящее время есть очень небольшое количество учебников и учебных пособий по французскому языку для студентов технических специальностей, отвечающих требованиям современных образовательных стандартов. Зарубежные издательства не уделяют данному вопросу должного внимания и не выпускают методик для «технарей». Преподаватели российских ВУЗов часто работают по внутренним 
узкоспециализированным изданиям, создаваемым и доступнымтолько им самим, так как подобные учебные пособия обычно не поступают в продажу, не выставляются на книжных ярмарках, а так и остаются достоянием одного ВУЗа, а то и одной кафедры.

Учитывая вышесказанное, следуетотметить, что преподавание нового иностранного языка «с нуля» (в нашем случае французского) студентам неязыковых ВУЗовпроходит иначе, чемобучениепервому «школьному» английскому. Оно коммуникативно, практически и профессионально ориентировано, проходит с опорой на русский и английский языки, его темпы гораздо выше. Методика проведения занятий по второму иностранному языку существенно отличается от методики обучения первому, что очень важно принимать во внимание в процессе лингвистической подготовки студентов неязыкового ВУЗа. Это позволяет выполнить со студентами ФГОС по специальности «Иностранный язык», используя несколько более упрощённую рабочую программу. И если не относиться к проблеме преподавания нового иностранного языка серьезно, если не мотивировать студентов современными формами и методами преподавания, более значительными окажутся доводы тех, кто полагает, что изучать новый язык в неязыковом вузе «с нуля» это напрасный труд, так как английский язык точно пригодится выпускнику в профессиональной деятельности, а другой -не обязательно.

В последнее время большая часть студентов всех профилей, в том числе технических,осознают важность лингвистической подготовки. Они понимают, что в настоящее время нет такого рода деятельности, в которой знание иностранных языков оказалось бы лишним. Большинство молодых людей стремятся стать не только хорошими профессионалами, но и всесторонне развитыми, высокообразованными личностями.Изучение и владение новыми иностранными языками обязательно внесет свой вклад в осуществление этого стремления.

$$
* * *
$$

1. Федеральный закон от 29.12.2012 N 273-Ф3 (ред. от 29.07.2017) «Об образовании в Российской Федерации».Статья 34, п. 4. URL: http://www.consultant.ru/document/cons_doc_LAW_140174/

2. Киреева 3. Р., Галимова Х. Х.Особенности обучения французскому языку как второму иностранному на языковом факультете //Филологические науки. Вопросы теории и практики: электрон.многопредм. науч. журн.Тамбов: Грамота, 2015. № 5 (47). Ч. I. С. 103 106.http://www.gramota.net/materials/2/2015/5-1/23.html

3. Синицына Т.А. Преподавание иностранного языка для студентов неязыковых вузов.Развитие образования, педагогики и психологии в современном мире. // Сборник научных трудов по итогам международной научно-практической конференции. Воронеж, 2016. № 3. С. 151.

4. Тенитилов С.В., Флеров О.В. Влияние современных педагогических идеалов на обучение иностранным языкам // Вестник Российского нового университета.№ 1. М.,2010. С. 95-99.

5. Флеров О.В. Особенности преподавания второго иностранного языка в нелингвистическом вузе // Современное образование. М., 2015.№ 1. С.1-25.

\section{Потёмкина Е.B. \\ История развития концепции «Словаря языка Достоевского»: от символа к тезаурусу}

Московский государственный университет имени М.В. Ломоносова (Россия, Москва)

doi: $10.18411 / s p c-26-12-2017-04$

idsp: 000001:spc-26-12-2017-04

\section{Аннотация}

Статья посвящена некоторым базовым положениям концепции «Словаря языка Достоевского», а также истории их разработки.Рассмотрена ключевая единица в структуре словаря, обозначаемая термином «идиоглосса».Описана предложенная Ю.Н. Карауловым и И.В. Ружицкимметодика построения авторского тезауруса на основе выделения символической парадигмы идиоглоссы. На основе анализа 